\title{
Effects of arginine, growth hormone-releasing hormone (GHRH) and neostigmine administered singly or in paired combinations on growth hormone $(\mathrm{GH})$ release in pigs
}

\author{
A Cochard $^{1 *}, \mathrm{R}_{\text {Guilhermet }}{ }^{1}, \mathrm{M}$ Bonneau ${ }^{2}$ \\ ${ }^{1}$ Laboratoire du jeune ruminant, Inra-Ensar, 65, rue de Saint-Brieuc, 35042 Rennes cedex; \\ ${ }^{2}$ Station de recherches porcines, Inra, 35590 Saint-Gilles, France
}

(Received 24 December 1996; accepted 30 July 1997)

\begin{abstract}
Summary - In human, arginine (ARG) induces growth hormone (GH) release, probably via a decrease in somatostatinergic tone. To assess the mechanism by which ARG mediates GH release in pigs, the effects on plasma GH release of ARG $(1 \mathrm{~g} / \mathrm{kg}$ body weight, infused between times -15 and $-5 \mathrm{~min}$ ), growth hormone-releasing hormone (GHRH, $2 \mu \mathrm{g} / \mathrm{kg}$, at time $0 \mathrm{~min}$ ) and neostigmine, a cholinesterase inhibitor (NEO, $50 \mu \mathrm{g} / \mathrm{kg}$, at time $4 \mathrm{~min}$ ), administered intravenously singly or in paired combinations were investigated in piglets between times -30 and $100 \mathrm{~min}$. ARG and GHRH had additive effects on GH release. No potentialization was observed between the two treatments. GH response was higher following the combination of NEO and GHRH treatments than after NEO or GHRH given alone. NEO had no further effect on ARG-induced GH secretion. Therefore, our results suggest that the mechanism by which ARG stimulates GH secretion in pig is the same as in human.
\end{abstract}

arginine / growth hormone-releasing hormone / neostigmine / growth hormone / pig

Résumé - Effets de l'arginine, du growth hormone-releasing hormone (GHRH) et de la néostigmine administrés seuls ou en combinaison deux à deux sur la sécrétion de l'hormone de croissance (GH) chez le porc. Chez l'homme, l'arginine (ARG) induit une sécrétion d'hormone de croissance, probablement via une diminution du tonus somatostatinergique. Pour déterminer le mécanisme par lequel l'ARG influence la sécrétion de GH chez le porc, les effets sur la GH plasmatique de l'ARG ( $1 \mathrm{~g} / \mathrm{kg}$ de poids vif, infusée de -15 à $-5 \mathrm{~min}$ ), du growth hormone-releasing hormone (GHRH, $2 \mu \mathrm{g} / \mathrm{kg}$, à $0 \mathrm{~min}$ ) et de la néostigmine, un inhibiteur cholinestérasique (NEO, $50 \mu \mathrm{g} / \mathrm{kg}$, à $4 \mathrm{~min}$ ), administrés par voie intraveineuse seuls ou en combinaison deux à deux ont été étudiés chez des porcelets entre -30 et $100 \mathrm{~min}$. L'ARG et le GHRH ont des effets additifs sur la sécrétion de GH. Aucune potentialisation n'a été observée entre ces deux traitements. La réponse de la GH était plus

\footnotetext{
* Correspondence and reprints

Tel: (33) 02992853 52; fax: (33) 02992853 70; e-mail: cochard@ roazhon.inra.fr
} 
élevée après le traitement combiné de NEO et de GHRH qu'après les traitements de NEO ou de GHRH seuls. Le NEO n'a pas d'effet supplémentaire sur la sécrétion de GH induite par l'ARG. Nos résultats suggèrent donc que le mécanisme par lequel l'ARG stimule la sécrétion de GH chez le porc est le même que chez l'homme.

arginine / growth hormone-releasing hormone / néostigmine / hormone de croissance / porc

\section{INTRODUCTION}

Growth hormone $(\mathrm{GH})$ secretion is regulated by many factors including nutrients. Arginine (ARG) infused intravenously at a dose of $0.5 \mathrm{~g} / \mathrm{kg}$ body weight is a wellknown stimulator of $\mathrm{GH}$ release in human (Alba-Roth et al, 1988; Page et al, 1988; Ghigo et al, 1990a) and can be used for the diagnosis of growth impairments. Few studies have been reported in domestic animals. Abomasal, intraduodenal or intravenous infusions of ARG can stimulate GH secretion in lambs (Davenport et al, 1990a, 1995), adult sheep (Hertelendy et al, 1969, 1970; Davis and Borger, 1973; Kuhara et al, 1991; Recabarren et al, 1995) and cattle (Vicini et al, 1988; Davenport et al, 1990b). Little is known about the effect of ARG on GH secretion in pigs. It seems that pigs are less sensitive to ARG than other species (Hertelendy et al, 1970). When infused intravenously at a dose of $0.5 \mathrm{~g} / \mathrm{kg}^{0.75}$ body weight, ARG induces a small rise in plasma $\mathrm{GH}$ in 12-week-old pigs (Atinmo et al, 1978).

ARG-induced GH release has been welldocumented in human and is thought to be mediated by a decrease in somatostatin release (Locatelli et al, 1986; Alba-Roth et al, 1988; Ghigo et al, 1990a; Volta et al, 1995). In that respect, $A R G$ has been shown to override inhibitory effects on GH secretion that are known to be mediated by an increase in somatostatin release, including glucose administration (Ghigo et al, 1992), obesity (Procopio et al, 1995; Martina et al, 1995), glucocorticoids (Giustina et al, 1992), advanced age (Ghigo et al, 1990b) and GH negative feedback (Massara et al, 1986;
Torsello et al, 1988; Kelijman and Frohman, 1991; Ghigo et al, 1991). Cholinesterase inhibitors, such as neostigmine (NEO) and pyridostigmine, which are known to decrease somatostatin release (Richardson et al, 1980; Muller, 1987) do not further increase $\mathrm{GH}$ response to $\mathrm{ARG}$ in human (Massara et al, 1986; Ghigo et al, 1990a, 1994; Procopio et al, 1995). On the contrary, the effect of ARG on GH secretion is blunted or abolished by cholinergic antagonists such as atropine (Casanueva et al, 1984) and pirenzepine (Delitala et al, 1982; Maccario et al, 1995), an acute increase in free fatty acids (Maccario et al, 1994) and an administration of a somatostatin analog (Masuda et al, 1990).

ARG probably acting by inhibiting somatostatin release from the hypothalamus is able to enhance $\mathrm{GH}$ response to GHRH in human (Alba-Roth et al, 1988; Page et al, 1988; Ghigo et al, 1990a, b, 1991, 1992, 1994). In a preliminary study conducted on eight pigs weighing $30-40 \mathrm{~kg}$, we applied the experimental design used in human studies (intravenous infusion of ARG over 30 $\min$ at the dose of $0.5 \mathrm{~g} / \mathrm{kg}$ ) but we were unable to demonstrate any increase in GHRH-induced GH release by ARG. The area under the GH curve (AUC) and the maximum of $\mathrm{GH}$ secretion were not significantly different between GHRH treatment and the combination of GHRH and ARG treatments $(P>0.1$, AUC: $200,488,446$ $\min \times \mathrm{ng} / \mathrm{mL}$, maximum of $\mathrm{GH}$ secretion: 8 , $11,11 \mathrm{ng} / \mathrm{mL}$ for ARG, GHRH and GHRH plus ARG, respectively). These results could be explained either by the existence of a somatostatinergic hypertone in pigs as previously suggested by the poor GH response 
to GHRH in this species (Della-Ferra et al, 1986; Etherton et al, 1986; Peticlerc et al, 1987) or by a different mechanism of action of ARG than that proposed in human.

The present study was therefore undertaken in order to determine whether the mechanism by which ARG mediates GH secretion in pigs is the same as in human. For that purpose, the effects of ARG, GHRH and NEO administered singly or in paired combinations were investigated in piglets with a modified experimental design compared to that used in human. The dose of ARG was double that used in human and the period of time over which ARG was infused was shorter.

\section{MATERIALS AND METHODS}

\section{Animals and management}

Six female crossbred Yorkshire $\times$ Pietrain piglets from three litters, two females per litter, were used in the experiment. They were 35 days of age and weighed $9.7 \pm 0.9$ (SE) $\mathrm{kg}$ at the beginning of the study. They were reared in compliance with national regulations for the human care and use of the animals in research. They were housed in individual pens throughout the experiment. They were allowed water ad libitum and fed $70 \mathrm{~g} / \mathrm{kg}^{0.75}$ body weight of a standard diet provided in two meals a day. On the days of treat- ments, the morning meal was delayed until the end of sampling. Animals were weighed the day before each treatment. They gained $6.2 \pm 0.5$ (SE) $\mathrm{kg}$ during the experiment.

Four days before the first injections, a catheter was inserted into one external jugular vein of each animal under general anesthesia $\left(\mathrm{O}_{2}\right.$ : halothane, $92: 8 \mathrm{v} / \mathrm{v}, 2 \mathrm{~mL} / \mathrm{min}$ ). Saline was flushed daily through the catheter to keep it patent throughout the experiment.

\section{Treatments and blood sampling}

Six treatments were applied consecutively to each animal at 3-day intervals according to $a 6 x$ 6 latin square design. The six treatments are described in table I. Arginine (Degussa, Paris, France), GHRH (synthetic human 1-29 amide fragment of GHRH, Sigma, MO, USA) and neostigmine (Prostigmine, Roche, Neuilly-surSeine, France) were administered intravenously through the catheter at doses of $1 \mathrm{~g} / \mathrm{kg}, 2 \mu \mathrm{g} / \mathrm{kg}$ and $50 \mu \mathrm{g} / \mathrm{kg}$ body weight, respectively. ARG, $20 \%$ in saline, was slowly injected by hand with a syringe at a flow rate of $10 \mathrm{~mL}$ per minute. No side-effect was observed during and after the infusion of ARG.

Blood samples were collected in heparinized tubes through the catheter at times $-30,-17,-2$, $5,10,15,20,25,30,35,40,50,60,70,80,90$ and $100 \mathrm{~min}$. Time 0 was 9.00 . Blood was cooled on ice then immediately centrifuged. Plasma was stored at $-20^{\circ} \mathrm{C}$ until analysis.

Table I. Treatments.

\begin{tabular}{lccc}
\hline & & \multicolumn{2}{c}{ Time $^{\mathrm{a}}$} \\
\cline { 2 - 4 } Treatments & -15 to $-5 \mathrm{~min}$ & 0 min & +4 min \\
\hline ARG & arginine & vehicle & vehicle \\
GHRH & vehicle & GHRH & vehicle \\
NEO & vehicle & vehicle & neostigmine \\
ARG/GHRH & arginine & GHRH & vehicle \\
ARG/NEO & arginine & vehicle & neostigmine \\
GHRH/NEO & vehicle & GHRH & neostigmine
\end{tabular}

a Time 0 was 9.00; arginine: $1 \mathrm{~g} / \mathrm{kg}$ body weight, $20 \%$ solution in saline; ${ }^{\mathrm{c}} \mathrm{GHRH}$ : $2 \mu \mathrm{g} / \mathrm{kg}, 20 \mu \mathrm{g} / \mathrm{mL}$ in isotonic glucose; ${ }^{\mathrm{d}}$ neostigmine: $50 \mu \mathrm{g} / \mathrm{kg}, 0.5 \mathrm{mg} / \mathrm{mL}$ in saline. 


\section{Measurement of plasma GH concentration}

Plasma GH concentration was determined by a specific homologous double-antibody radioimmunoassay as previously described (Louveau et al, 1991) using a specific antibody raised in rabbit (UCB Bioproducts, Brussels, Belgium). USDA-GH-I-1 (AFP-6400) was used for iodination and standard curve. Sensitivity was 0.75 $\mathrm{ng} / \mathrm{mL}$. Cross-reactivity with porcine prolactin, porcine luteinizing hormone, and porcine folliclestimulating hormone was $<0.4 \%$. Intra-assay coefficients of variation were 9,13 and $15 \%$ for plasma samples containing $4.9,15.2$ and 32.9 $\mathrm{ng} / \mathrm{mL}$, respectively. All samples were measured in duplicate within a single assay.

\section{Data analysis}

Area under the GH curve (AUC) was estimated between times -17 and $100 \mathrm{~min}$ by calculating the area between the GH curve and basal level extended to $100 \mathrm{~min}$. Basal level was obtained by calculating the mean of $\mathrm{GH}$ levels at times -30 and $-17 \mathrm{~min}$.

Data were analysed by analysis of variance using the generalized linear model (GLM) procedure of SAS system (SAS, 1989). GH profiles were analysed using the repeated procedure of SAS including the main effects of the day of treatment, animal and treatment. The main effect of time was analysed within treatments. Mean GH levels were compared to basal levels using Dunnettu test. The model used for the analysis of areas under the GH curve included the main effects of day of treatment, animal and treatment. Multiple comparison of the means for treatments and AUC was carried out using Duncan test.

Three variables (ARG+GHRH, ARG+NEO and GHRH+NEO) were constructed in order to test respectively the additive effects between ARG and GHRH, between ARG and NEO, and between GHRH and NEO. Plasma GH above basal level measured for ARG and GHRH were summed up at all times studied. The same procedure was applied for ARG and NEO, and for GHRH and NEO. ARG + GHRH, ARG + NEO, and GHRH + NEO were compared to plasma GH above basal level obtained for ARG/GHRH, ARG/NEO and GHRH/NEO, respectively.

\section{RESULTS}

GH profiles from time -30 min to time 100 min and $\mathrm{AUC}$ are shown in figure 1 and in figure 2 , respectively.

Basal plasma GH levels did not differ significantly between treatments $(P>0.1)$. Each treatment induced an increase in plasma GH whose magnitude and timerelated pattern differed between treatments $(P<0.001)$. Each piglet responded to all treatments except one for NEO.

\section{Plasma GH responses to ARG, GHRH, or NEO singly administered}

GH responses to ARG and GHRH treatments were similar in magnitude (AUC: $P>$ 0.05 ) and much higher than GH response to NEO (AUC: $P<0.05$ ). Plasma GH was significantly $(P<0.05)$ higher than basal levels between -2 and $50 \mathrm{~min}, 10$ and 80 min, and 15 and 40 min for ARG, GHRH and NEO treatments, respectively. Maximum GH response occurred earlier with ARG than with GHRH or NEO. Maximum GH responses were observed at 5,25 and 25 min for ARG, GHRH and NEO, respectively.

\section{Plasma GH response to combined ARG and GHRH treatments}

The combined administration of ARG and GHRH elicited a larger GH response compared to ARG or GHRH alone (AUC: $P<$ 0.05 ). GH levels for ARG/GHRH treatment were significantly higher than those induced by ARG alone from -2 to $35 \min (P<0.05)$ and than those induced by GHRH alone from 5 to $80 \mathrm{~min}(P<0.05)$. GH profile for ARG/GHRH treatment exhibited two peaks, which rose at the same times as those for the ARG and GHRH treatments. Plasma GH was significantly lower at time $20 \mathrm{~min}$ compared to times 10 and $25 \mathrm{~min}(P<0.05)$. 

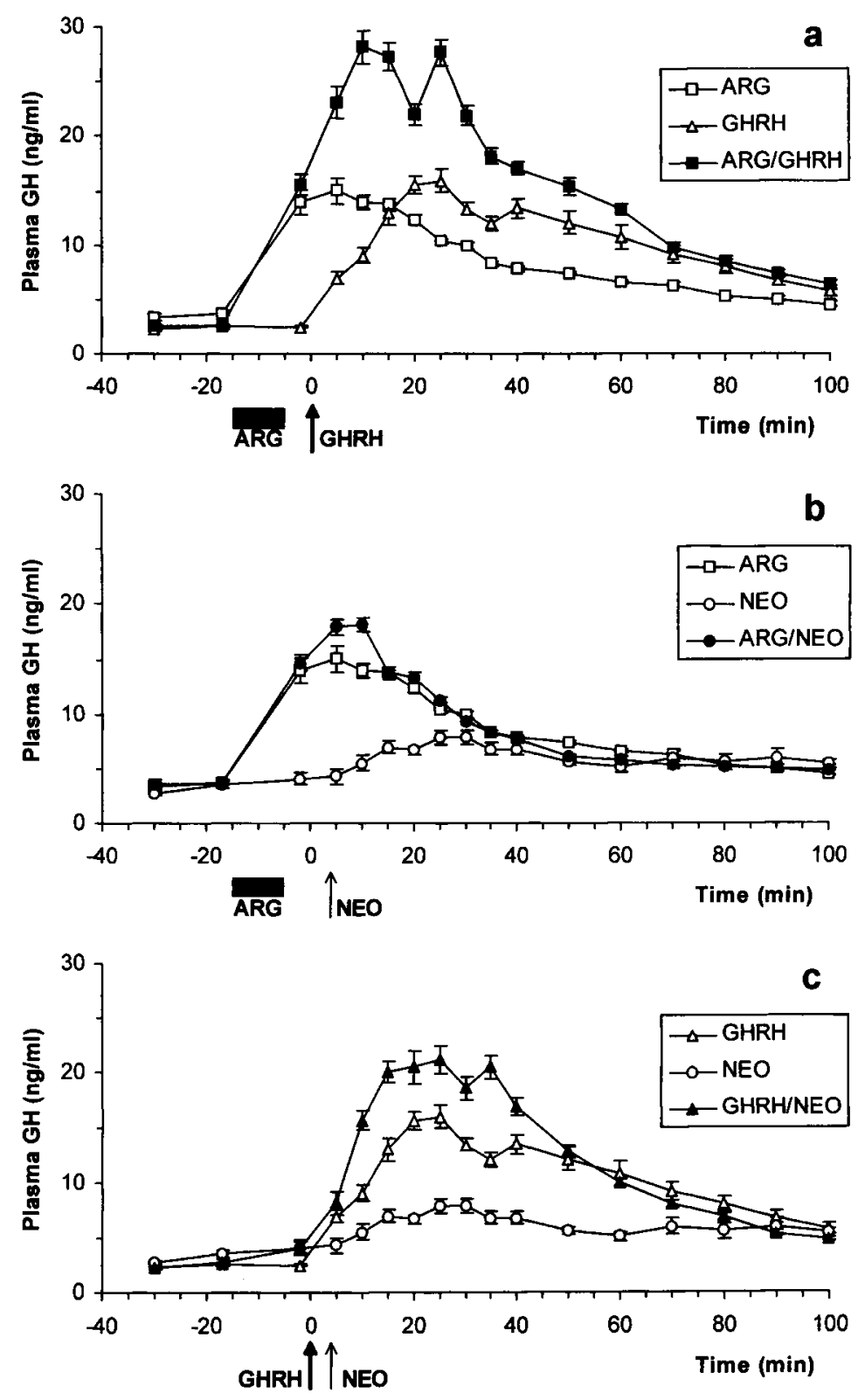

Fig 1. Plasma GH responses (means $\pm S E M$ ). Comparison of paired combination treatments with treatments alone. (a) Plasma GH responses to arginine (ARG), to growth hormone-releasing hormone (GHRH), and to ARG plus GHRH (ARG/GHRH). (b) Plasma GH responses to ARG, to neostigmine (NEO), and to ARG plus NEO (ARG/NEO). (c) Plasma GH responses to GHRH, to NEO, and to GHRH plus NEO (GHRH/NEO). Plasma GH concentrations were determined as indicated in Material and methods. 


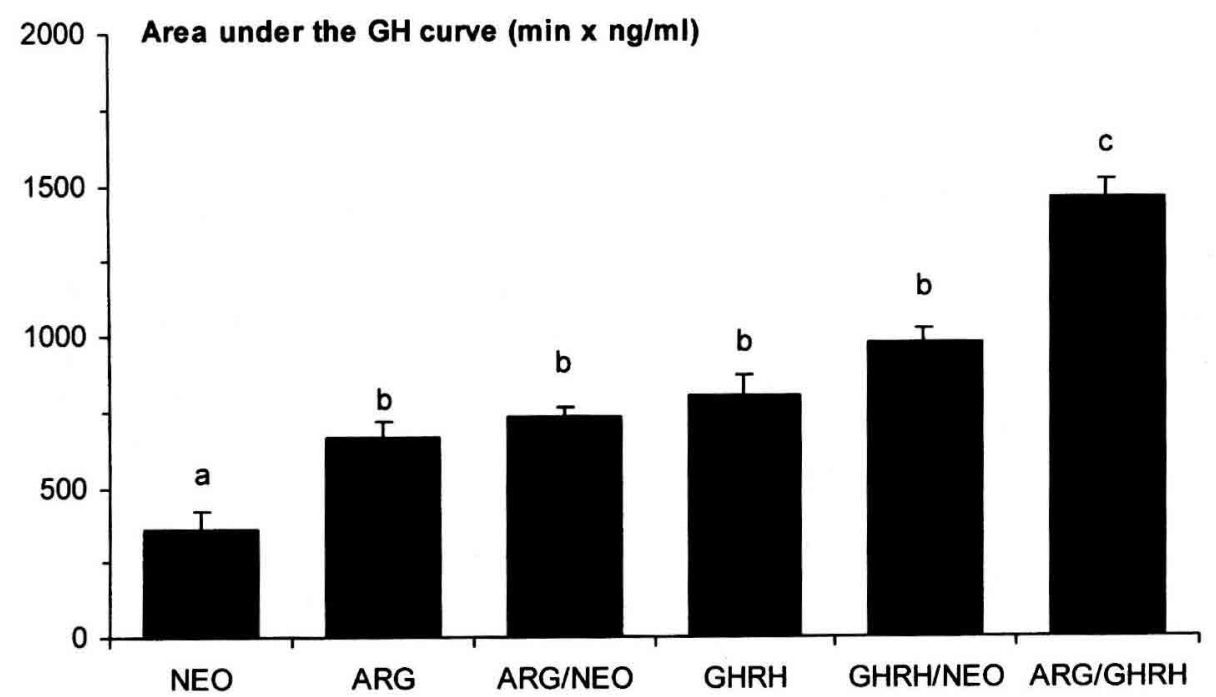

Fig 2. Plasma GH responses ( $\mathrm{AUC} \pm \mathrm{SEM}$ ) to arginine (ARG), growth hormone-releasing hormone (GHRH), neostigmine (NEO), and to the combined administrations of ARG and GHRH (ARG/GHRH), of ARG and NEO (ARG/NEO), and of GHRH and NEO (GHRH/NEO). AUC were estimated as indicated in Materials and methods. Columns with different letters differ $(P<0.05)$.

The sums of $\mathrm{GH}$ values above basal level for ARG and GHRH treatments were not statistically different from values above basal level for ARG/GHRH $(P>0.05)$ demonstrating that the effects of ARG and GHRH were additive. The additivity of those effects is further demonstrated by AUC values.

\section{Plasma GH response to combined ARG and NEO treatments}

Plasma GH levels did not differ between ARG and ARG/NEO treatments (AUC: $P>0.05$ ). Plasma GH concentrations were higher after ARG/NEO treatment than after NEO treatment between -2 and $10 \min (P<$ 0.05 , AUC: $P<0.05$ ). The peak of $\mathrm{GH}$ secretion after ARG/NEO was observed at $10 \mathrm{~min}$.

\section{Plasma GH response to combined GHRH and NEO treatments}

Plasma GH levels were higher after GHRH/NEO than after GHRH treatment at $10 \mathrm{~min}(P<0.10), 15,30$ and $35 \mathrm{~min}(P<$ $0.05)$. AUC was higher for GHRH/NEO than for GHRH; however, the difference was not significant $(P>0.05)$. Plasma GH differed significantly $(P<0.05)$ between the GHRH/NEO and NEO treatments from 10 to $60 \mathrm{~min}$. The AUC calculated for NEO and GHRH/NEO differed significantly $(P<0.001)$. Maximal secretion for GHRH/NEO was observed between 15 and $35 \mathrm{~min}$. The sums of $\mathrm{GH}$ levels above basal level for GHRH and NEO treatments were not statistically different from values above basal level for GHRH/NEO $(P>0.05)$ suggesting that the effects of NEO and GHRH could be additive. 


\section{DISCUSSION}

ARG has been shown to induce $\mathrm{GH}$ release in human as well as in domestic animals including pigs. In human, ARG effect is probably mediated by a decrease in somatostatinergic tone. To determine if the same mechanism occurs in pigs, we investigated the effects of ARG, GHRH and NEO administered singly or in paired combinations on GH release in piglets. In a preliminary study, we applied the experimental design used in human (ARG infused over $30 \mathrm{~min}$ at a dose of $0.5 \mathrm{~g} / \mathrm{kg}$ body weight) on pigs weighing $30-40 \mathrm{~kg}$ but we were unable to observe any increase in GHRH-induced GH release by ARG. Owing to a hypothesized somatostatinergic hypertone in pigs, we therefore infused ARG on a shorter period $(10 \mathrm{~min})$ and we doubled the dose of ARG $(1 \mathrm{~g} / \mathrm{kg})$ in the present study.

ARG when infused at a dose of $1 \mathrm{~g} / \mathrm{kg}$ induced a clear GH response in all pigs of the present study, whereas a much smaller response was obtained with smaller doses in previous studies with pigs. A dose of 0.5 $\mathrm{g} / \mathrm{kg}^{0.75}$ body weight induced a limited increase in plasma GH (Atinmo et al, 1978). A dose of $0.5 \mathrm{~g} / \mathrm{kg}$ body weight, the same as that used in human studies, resulted in no or little GH response (Hertelendy et al, 1970; our own preliminary results). Together with the observation that GH response to NEO alone was small, these data are consistent with an elevated somatostatinergic tone in the pig as previously suggested by inconsistent $\mathrm{GH}$ responses to GHRH and the need for higher GHRH doses in pigs compared to other species (Della-Ferra et al, 1986; Etherton et al, 1986; Peticlerc et al, 1987). The dose of GHRH used in our study was optimal for the secretion of $\mathrm{GH}$ in pigs weighing $10-20 \mathrm{~kg}$ as determined previously (our unpublished results) and is smaller than the one necessary to elicit maximal GH response in older and heavier pigs (Peticlerc et al, 1987).
ARG and GHRH had additive effects on plasma GH in the pigs of the present study. The combination of NEO and GHRH treatments also resulted in a higher $\mathrm{GH}$ response than NEO or GHRH given alone although one could have expected a larger difference as previously observed in GHRH pigs immunized against somatostatin (Dubreuil et al, 1989). This is probably related to the fact that the NEO dose used in the present experiment was not optimal so that the additivity of the effects of NEO and GHRH was not clearly demonstrated particularly with the AUC. The combined administration of ARG and NEO had no further effect compared to ARG alone. These results are consistent with a common mechanism of action for NEO and ARG. Otherwise, we would have had a higher $\mathrm{GH}$ response after the combination of ARG and NEO treatments than after ARG given alone. This common mechanism of action involves somatostatin pathway as described for NEO (Richardson et al, 1980) and not GHRH pathway. The present results are also consistent with different mechanisms of action for ARG and GHRH since the actions of ARG and GHRH were additive. It may therefore be hypothesized that ARG induces a decrease in the somatostatinergic tone in pigs as described in human (Locatelli et al, 1986; Alba-Roth et al, 1988; Ghigo et al, 1990a, Volta et al, 1995). The mechanisms by which ARG could inhibit somatostatin release in the hypothalamus remain to be investigated. ARG could act directly or via its metabolites. ARG can be metabolized in the brain to ornithine by brain arginase (Carjaval et al, 1995 ) and then to glutamic acid via ornithine aminotransferase (Wroblewsky et al, 1985). Both metabolites have been shown to stimulate $\mathrm{GH}$ secretion. Ornithine elicits $\mathrm{GH}$ secretion in sheep (Davenport et al, 1990a, 1995; Recabarren et al, 1995). Glutamic acid is able to stimulate $\mathrm{GH}$ release in pigs (Barb et al, 1996). ARG is also the precursor of nitric oxide (NO), which is synthesized by NO synthase (NOS) (Palmer et al, 
1988). NOS has been localized in various hypothalamic areas and in the pituitary. NO, which is involved in a wide range of physiological events (Moncada et al, 1991), seems to play a permissive role in the control of stimulated $\mathrm{GH}$ release. Endogenous NO deprivation by the use of NOS inhibitors attenuates glutamic acid-induced GH release (Tenasempere et al, 1995) and GHRHinduced GH secretion in prepubertal rats (Tenasempere et al, 1996) but not basal GH. Further studies are needed to determine whether ARG could stimulate NOergic neurons in the hypothalamus.

A potentiating effect between ARG and GHRH on GH release has been described in human (Alba-Roth et al, 1988; Page et al, 1988; Ghigo et al, 1990b, 1991, 1992, 1994) except with children of short stature (Ghigo et al, 1990a). In the pigs of the present study, the effects of ARG and GHRH were only additive and no potentialization could be demonstrated. Further studies are needed to establish if this potentialization only occurs in adult animals and human or if there are species differences.

In conclusion, the present results suggest that a higher dose of ARG in pigs compared to human is required to obtain a significant GH response owing to a high somatostatinergic tone. The mechanism by which ARG stimulates GH secretion in pigs seems to be the same as the one proposed in human. In human, ARG-induced GH release is probably mediated by a decrease in somatostatin release although this mechanism was demonstrated indirectly by the use of a cholinesterase inhibitor as in the present study. Direct measurements of somatostatin and GHRH in the hypothalamo pituitary portal vein in pigs are therefore needed to verify definitively these hypotheses.

\section{ACKNOWLEDGMENTS}

The authors express their thanks to Y Lebreton, F Giovanni, M Formal and M Lesage for their contribution to the experiment. The GH preparation was a gift from the National Hormone and Pituitary Program (University of Maryland School of Medecine) and the National Institute of Diabetes and Kidney diseases.

\section{REFERENCES}

Alba-Roth J, Muller A, Schopohl J, von Werder K (1988) Arginine stimulates growth hormone secretion by suppressing endogenous somatostatin secretion. J Clin Endocrinol Metab 67, 1186-1189

Atinmo T, Baldijao C, Houpt KA, Pond WG, Barnes RH (1978) Plasma levels of growth hormone and insulin in protein malnourished $v s$ normal growing pigs in response to arginine or glucose infusion. J Anim Sci 46, 409-416

Barb CR, Campbell RM, Armstrong, Cox NM (1996) Aspartate and glutamate modulation of growth hormone secretion in the pig: possible site of action. Dom Anim Endocrinol 13, 81-90

Carvajal N, Torres C, Uribe E, Salas M (1995) Interaction of arginase with metal ions: studies of the enzyme from human liver and comparison with other arginases. Comp Biochem Physiol [B] 112, 153-159

Casanueva FF, Villanueva L, Cabranes JA, CabezasCerrato J, Fernandez-Cruz A (1984) Cholinergic mediation of growth hormone secretion elicited by arginine, clonidine, and physical exercise in man. $J$ Clin Endocrinol Metab 59, 526-530

Davenport GM, Boling JA, Schillo KK, Aaron DK (1990a) Nitrogen metabolism and somatotropin secretion in lambs receiving arginine and ornithine via abomasal infusion. J Anim Sci 68, 222-232

Davenport GM, Boling JA, Schillo KK (1990b) Nitrogen metabolism and somatotropin secretion in beef heifers receiving abomasal arginine infusions. $J$ Anim Sci 68, 1683-1692

Davenport GM, Boling JA, Schillo KK (1995) Growth and endocrine responses of lambs fed rumen-protected ornithine and arginine. Small Ruminant Res $17,229-236$

Davis SL, Borger ML (1973) Hypothalamic catecholamine effects on plasma levels of prolactin and growth hormone in sheep. Endocrinology 92, 303 309

Delitala G, Frulio T, Pacifico A, Maioli M (1982) Participation of cholinergic muscarinic receptors in glucagon- and arginine-mediated growth hormone secretion in man. $J$ Clin Endocrinol Metab 55 , 1231-1233

Della-Ferra MA, Buonomo FC, Baile CA (1986) Growth hormone-releasing factors and secretion of growth hormone in sheep, calves and pigs. Dom Anim Endocrinol 3, 165-176 
Dubreuil P, Pelletier G, Peticlerc D, Lapierre H, Gaudreau P, Brazeau P (1989) Effects of active immunization against somatostatin on serum growth hormone concentration in growing pigs: influence of fasting and repetitive somatocrinin injections. Endocrinology 125, 1378-1384

Etherton TD, Wiggins JP, Chung CS, Evock CM, Rebhun JF, Walton PE (1986) Stimulation of pig growth performance by porcine growth hormone and growth hormone releasing factor. J Anim Sci 63, 1389-1399

Ghigo E, Bellone J, Mazza E, Imperiale E, Procopio M, Valente F, Lala R, de Sanctis C, Camanni F (1990a) Arginine potentiates the GHRH- but not the pyridostigmine-induced GH secretion in normal short children. Further evidence for a somatostatin supressing effect of arginine. Clin Endocrinol 32, 763-767

Ghigo E, Goffi F, Nicolosi M, Arvat E, Valente F, Mazza E, Ghigo MC, Camanni F (1990b) Growth hormone (GH) responsiveness to combined administration of arginine and GH-releasing hormone does not vary with age in man. $J$ Clin Endocrinol Metab 71, 1481-1485

Ghigo E, Arvat E, Valente F, Nicolosi M, Boffano GM, Procopio M, Bellone J, Mazza E, Camanni F (1991) Arginine reinstates the somatotrope responsiveness to intermittent growth hormone-releasing hormone administration in normal adults. $\mathrm{Neu}$ roendocrinology 54, 291-294

Ghigo E, Miola C, Aimaretti G, Valente F, Arvat E, Yin-Zhang W, Camanni F (1992) Arginine abolishes the inhibitory effect of glucose on the growth hormone response to growth hormone-releasing hormone in man. Metabolism 41, 1000-1003

Ghigo E, Arvat E, Gianotti L, Ramunni J, Maccario M, Camanni F (1994) Interaction of salbutamol with pyridostigmine and arginine on both basal and GHRH-stimulated GH secretion in humans. Clin Endocrinol 40, 799-802

Giustina A, Bossoni S, Bodini C, Girelli A, Balestrieri GP, Pizzocolo G, Wehrenberg WB (1992) Arginine normalizes the growth hormone response to GHRH in adult patients receiving chronic daily immunosuppressive glucocorticoid therapy. J Clin Endocrinol Metab 74, 1301-1305

Hertelendy F, Machlin L, Kipnis DM (1969) Further studies on the regulation of insulin and growth hormone secretion in sheep. Endocrinology 84, 192 199

Hertelendy F, Takahashi K, Machlin LJ, Kipnis DM (1970) Growth hormone and insulin secretory responses to arginine in the sheep, pig, and cow. Gen Comp Endocrinol 14, 72-77

Kelijman M, Frohman LA (1991) The role of the cholinergic pathway in growth hormone feedback. $J$ Clin Endocrinol Metab 72, 1081-1087

Kuhara T, Ikeda S, Ohneda A, Sasaki Y (1991) Effects of intraveinous infusion of 17 amino acids on the secretion of $\mathrm{GH}$, glucagon, and insulin in the sheep. Am J Physiol 260, E21-E26

Locatelli V, Torsello A, Redaelli M, Ghigo E, Massara F, Muller EE (1986) Cholinergic agonist and antagonist drugs modulate the growth hormone response to growth hormone-releasing hormone in the rat: evidence for mediation by somatostatin. $J$ Endocrinol 111, 271-278

Louveau I, Bonneau M, Salter DN (1991) Age-related changes in plasma porcine growth hormone $(\mathrm{GH})$ profiles and insulin-like growth factor-I (IGF-I) concentrations in Large-White and Meishan pigs. Reprod Nutr Develop 31, 205-216

Maccario M, Procopio M, Loche S, Cappa M, Martina V, Camanni F, Ghigo E (1994) Interaction of free fatty acids and arginine on growth hormone secretion in man. Metabolism 43, 223-226

Maccario M, Procopio M, Grottoli S, Oleandri SE, Razzone P, Camanni F, Ghigo E (1995) In obesity the somatotrope response to either growth hormone-releasing hormone or arginine is inhibited by somatostatin or pirenzepine but not by glucose. J Clin Endocrinol Metab 80, 3774-3778

Martina V, Bruno G, Tagliabue M, Bertaina S, Maccario M, Grottoli S, Procopio M, Ozzello A, Camanni F (1995) Blunted GH response to growth hormone-releasing hormone (GHRH) alone or combined with arginine in non-insulin-dependent diabetes mellitus. Horm Met Res 27, 26-30

Massara F, Ghigo E, Molinatti P, Mazza E, Locatelli V, Muller EE, Camanni F (1986) Potentiation of cholinergic tone by pyridostigmine bromide reinstates and potentiates the growth hormone reponsiveness to intermittent administration of growth hormone-releasing hormone. Acta Endocrinol 113, 12-16

Masuda A, Shibasaki T, Hotta M, Yamauchi N, Ling N, Demura H, Shizume K (1990) Insulin-induced hypoglycemia, L-dopa and arginine stimulate $\mathrm{GH}$ secretion through different mechanisms in man. Regul Peptides 31, 53-64

Moncada S, Palmer RMJ, Higgs EA (1991) Nitric oxide: physiology, pathophysiology, and pharmacology. Pharmacol Rev 43, 109-142

Muller EE (1987) Neural control of growth hormone secretion. Physiol Rev 67, 962-1035

Page MD, Dieguez C, Valcani R, Edwards C, Hall R, Scanlon MF (1988) Growth hormone (GH) response to arginine and L-dopa alone or after GHRH pretreatment. Clin Endocrinol 28, 551-558

Palmer RMJ, Rees DD, Ashton DS, Moncada S (1988) L-arginine in the physiological precursor for the formation of nitric oxide in endothelium dependent relaxation. Biochem Biophys Res Commun $153,1251-1256$

Peticlerc D, Pelletier G, Lapierre H, Gaudreau P, Couture Y, Dubreuil P, Morisset J, Brazeau P (1987) Dose response of two synthetic human growth hor- 
mone-releasing factors on growth hormone release in heifers and pigs. J Anim Sci 65, 1996-1005

Procopio M, Invitti C, Maccario M, Grottoli S, Cavagnini F, Camanni F, Ghigo E (1995) Effect of arginine and pyridostigmine on the GHRH-induced $\mathrm{GH}$ rise in obesity and Cushing's syndrome. Int $J$ Obesity 19, 108-112

Recabarren SE, Urrucelqui A, Robbiano M, Lobos A, Orellana P, Parilo J (1995) Effect of arginine and ornithine infusions on secretion of the growth hormone in prepubertal ewes. Arch Med Vet 27, 99104

Richardson SB, Hollander CS, D'Eletto R, Greenleaf PW, Thaw C (1980) Acetylcholine inhibits the release of somatostatin from rat hypothalamus in vitro. Endocrinology 107, 122-129

SAS (1989) SAS User's Guide. SAS Institute, Cary, NC, USA

Tenasempere M, Pinilla L, Aguilar E (1995) A possible role for endogenous nitric oxide (NO) in kainicacid (KA)-induced growth hormone $(\mathrm{GH})$ release in prepubertal rats. Neuroendocrinol Lett 17, 251-257

Tenasempere M, Pinilla L, Gonzalez D, Aguilar E (1996) Involvement of endogenous nitric oxide in the control of pituitary responsiveness to different elicitors of growth hormone release in prepubertal rats. Neuroendocrinology 64, 146-152

Torsello A, Panzeri G, Cermenati P, Caroleo C, Ghigo E, Camanni F, Muller EE, Locatelli V (1988) Involvement of the somatostatin and cholinergic systems in the mechanism of growth hormone autofeedback regulation in the rat. $J$ Endocrinol 117 , 273-281

Vicini JL, Clark JH, Hurley WL, Bahr JM (1988) Effects of abomasal or intraveinous administration of arginine on milk production, milk composition, and concentrations of somatotropin and insulin in plasma of dairy cows. J Dairy Sci 71, 658-665.

Volta C, Bernasconi S, Iughetti L, Ghizzoni L, Rossi M, Costa M, Cozzini A (1995) Growth hormone response to growth hormone-releasing hormone (GHRH), insuline, clonidine and arginine after GHRH pretreatment in obese children: evidence of somatostatin increase? Eur J Endocrinol 132, 716-721

Wroblewsky JT, Blaker WD, Meek JL (1985) Ornithine as a precursor of neurotransmitter glutamate: effects of canaline on ornithine aminotransferase activity and glutamate content in the septum of rat. Brain Res 329, 161-172 